\title{
AUTOMATIC FISH GRILLER BASED ON TEMPERATURE CONTROLLER
}

\author{
Sagita Rochman*, Roib Mukodah \\ Department of Electrical Engineering, \\ Faculty of Engineering, University of PGRI Adi Buana Surabaya \\ *Corresponding Email address: sagita@ unipasby.ac.id
}

\begin{abstract}
The automatic fish grill is a tool that is very helpful for food vendors who are processed in a roasting manner. For now, conventional automatic grills that are already on the market have very expensive prices so that many traders still use manual fish grills which are less efficient in the process of doing them. The purpose of making this automatic fish grill design is to help human work to save more time and energy. The automatic fish roasting box is designed with heat absorbers in each layer, equipped with two racks, each measuring $50 \mathrm{~cm}$ and also equipped with 2250 watt heaters. From the test results using different types of carp with different weights, it shows that the automatic fish grill works well and gets a 100\% percentage result with evenly cooked fish. The economical level of automatic fish grill has a good value, the whole design of automatic fish grill uses good quality materials and materials. For now, automatic roasters on the market have very expensive prices, this difference in price has made many traders not take full advantage of the technology. Because of this problem, researchers created an automatic fish grill based on a temperature controller, which is targeted at an inexpensive price, but can still be used safely and with maximum results. Thus, using a temperature controller-based automatic fish grill design can help simplify work to make it more efficient and safer.
\end{abstract}

Keywords: Grill, Automatic, Temperature, Efficient

\section{INTRODUCTION}

At this time the food menu that is cooked using a grill is in great demand by the public because it can reduce the amount of cholesterol in food, so a special grill is needed that can process food properly.
Therefore it is recommended for adults to choose foods that are low in cholesterol. Of the many street vendors and restaurants that provide grill dishes such as grilled chicken, grilled fish, roast meat, roast duck and so on. The roasting utensils used mostly still use manual roasters. This grill is made in the presence of a charcoal fuel storage basin whose air supply is given manually with human assistance to drive the fan and some use an electric fan to stabilize the charcoal. The operation of this tool has many shortcomings, namely the heat generated from the charcoal is not maximal, the fan speed still depends on humans so that the level of cooking can not be controlled properly and cholesterol levels in food are still high.

This automatic fish grill is only an alternative, not a substitute for charcoal fuel, which can create the distinctive taste of grilled fish. Charcoal grills will produce smoke which will pollute the surrounding air and over time will cause respiratory infections if inhaled continuously by humans. To shorten baking time and make work more effective. Researchers are motivated to design an automatic fish grill based on a temperature controller. Where later this tool has advantages compared to traditional grills, namely, it can grill fish automatically, can control the level of cooking maturity which is controlled by a temperature sensor, the controller is designed to make it easier to regulate and monitor the desired heat temperature. This system consists of a Power Supply, a series of controllers, a series of temperature sensors, drivers, heating elements (heater), Buzzer and LCD which functions as a display. If the previous roasting still used 
charcoal, in this modern era researchers will create an automatic roaster using electrical energy that is flowed through a low-power nickeline wire heating element. When compared to charcoal grills, the heating process of a grill that uses a heating element will be faster because it uses electricity as the main energy source.

\section{METHOD}

The design of this automatic fish grill was carried out from April 2019 to June 2019, at the Lab. Electrical, Electrical Engineering Study Program, FTI, Universitas PGRI Adi Buana Surabaya.

The scope of this research is to make a lower temperature limit of $29^{\circ} \mathrm{C}$ and an upper limit temperature of $36^{\circ} \mathrm{C}$, using MCS51 software programming, AT89S52

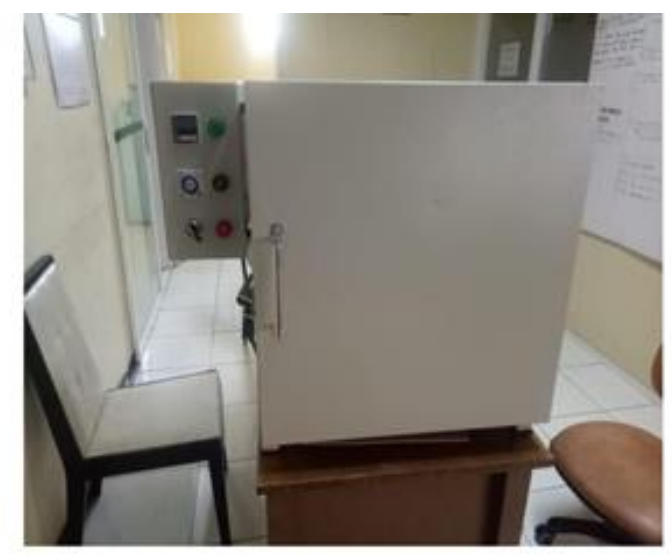

Gambar 1.I Tampak Belakang Pemanggang Otomatis

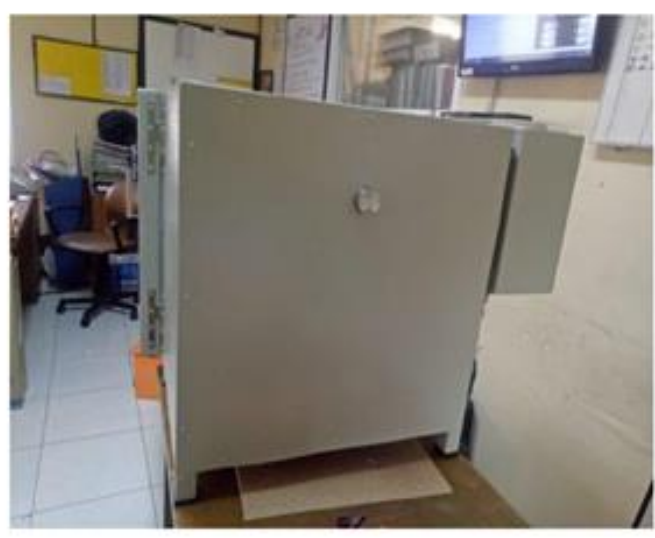

Gambar 1.2 Tampak Belakang Pemanggang Otomatis
Microcontroller IC, DS18B20 temperature sensor, using a seven segment display. The variables in this study consisted of the independent variable, namely the temperature sensor, and the dependent variable, namely the alarm on the incubator.

The data collection method uses the observation method which observes the work of the tool when it is operational. While the data analysis method uses descriptive analysis, which describes the work of the tool by measuring the parameters and outlined in the form of tables and graphs.

\section{RESULTS AND DISCUSSION a. Results of Design of Automatic Fish Grills based on Temperature Controller}

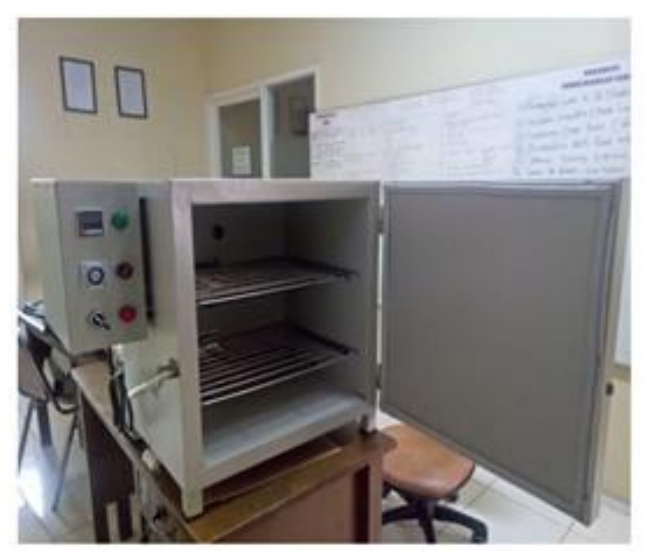

Gambar 1.3 Tampak Dalam Pemanggang Otomatis

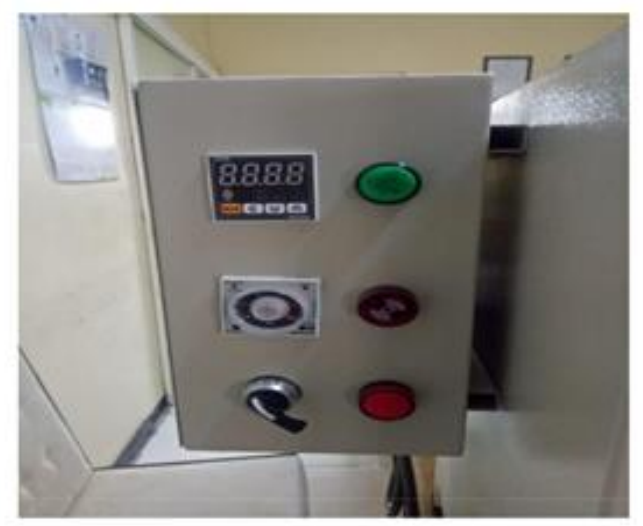

Gambar 1.4 Tampak Display dan Tombol Pemanggang Otomatis 
BEST

Journal of Applied Electrical \& Science Technology - University of PGRI Adi Buana

p-ISSN 2715-2871

e-ISSN 2714-5247

\section{a. Presentation of Power Efficiency Data}

In the power efficiency test below, it aims to determine the power value when the fish grill operates, so that it is converted to the $\mathrm{kWh}$ calculation with the formula

$$
\text { N ilai } k W h=\frac{\text { Nilai Daya }}{1000} \quad \begin{aligned}
& x \text { jumlah } \\
& \text { jam }
\end{aligned}
$$

Keterangan :

Nilai Daya = Nilai daya yang diperoleh dari pengukuran

$1 \mathrm{kWh} \quad=\quad \begin{array}{cl}1 & \begin{array}{l}\text { konversi ke kilowatt } \\ \text { hour }\end{array}\end{array}$

Jumlah jam = Waktu (jam) yang dibutuhkan untuk operasional

Researchers conducted sampling for 5 hours, the sampling process was carried out every 1 hour so that the value of power $(\mathrm{kWh})$ was found. The heater works at 100-500 watts of power per grill

Tabel 1. Penyajian efisiensi daya dengan suhu $100^{\circ} \mathrm{C}$

\begin{tabular}{|c|c|c|c|}
\hline $\begin{array}{c}\text { Time } \\
\text { (hours) }\end{array}$ & $\begin{array}{c}\text { Power } \\
\text { (watt) }\end{array}$ & $\begin{array}{c}\text { Value } \\
(\mathbf{k W h})\end{array}$ & $\begin{array}{c}\text { Temp } \\
\left({ }^{\circ} \mathbf{C}\right)\end{array}$ \\
\hline 1 & 500 & 0,5 & $100^{\circ} \mathrm{C}$ \\
\hline 2 & 450 & 0,9 & $100^{\circ} \mathrm{C}$ \\
\hline 3 & 100 & 1,32 & $100^{\circ} \mathrm{C}$ \\
\hline 4 & 440 & 1,96 & $100^{\circ} \mathrm{C}$ \\
\hline 5 & 480 & 2,4 & $100^{\circ} \mathrm{C}$ \\
\hline Average & $\mathbf{4 7 2}$ & $\mathbf{1 , 4}$ & $100^{\circ} \mathrm{C}$ \\
\hline
\end{tabular}

In the $\mathrm{kWh}$ test, the automatic grill is proven to have better efficiency because the power produced is smaller than a grill that uses a large power heater. The roaster in this study has an average power of 472 Watt with an average $\mathrm{kWh}$ of $1.4 \mathrm{kWh}$.

This provides an economical advantage to users with a small scale compared to conventional roasters if calculated with the above formula when the maximum usage is 500 watts, the result reaches $2.5 \mathrm{kWh}$ in 5 hours of use.

\section{c. Presentation of Accuracy Data for Fish Marker Alarm Function is Ripe}

Table 2. Data presentation of the level of maturity of the type of gouramy with weight variations

\begin{tabular}{|c|c|c|c|}
\hline $\begin{array}{c}\text { Fish } \\
\text { Weight } \\
(\mathbf{k g})\end{array}$ & $\begin{array}{c}\text { Temp } \\
\left({ }^{\circ} \mathbf{C}\right)\end{array}$ & $\begin{array}{c}\text { Time } \\
(\text { minute) }\end{array}$ & Product \\
\hline 0,5 & $100^{\circ} \mathrm{C}$ & 25 & done \\
\hline 1 & $100^{\circ} \mathrm{C}$ & 35 & done \\
\hline 1,5 & $100^{\circ} \mathrm{C}$ & 45 & done \\
\hline 2 & $100^{\circ} \mathrm{C}$ & 50 & done \\
\hline 2,5 & $100^{\circ} \mathrm{C}$ & 55 & done \\
\hline
\end{tabular}

The sensors and timers used to monitor the temperature in the fish grill function properly, as evidenced by the accuracy of the alarm function testing was carried out five times on types of carp with different weights, the temperature in each test was set at $100^{\circ}$ $\mathrm{C}$, for each trial. in settings ranging from $25-$ 55 minutes. And the accuracy value of the alarm sound is good and results in perfect fish maturity.

\section{CONCLUSION}

1. Grills have a good power efficiency rating compared to conventional grills which require high wattage

2. The economical level of the grill has a good value, the whole design costs Rp. $3,000,000$, this value is very far from being compared to conventional roasters which reach Rp. 6,000,000 to Rp.

3. $100 \%$ accuracy percentage with an alarm sound function when the roasting process is complete with mature results.

\section{ACKNOWLEDGMENTS}

1. Mr Akbar Sujiwa, S.Si., M.Si. as Chair of the Electrical Engineering Study Program, Faculty of Engineering, Adi Buana University of PGRI Surabaya. 
2. Mr Drs. Budi Prijo Sembodo, S.T., M.Kom. as Test Lecturer 1 and Lecturer, Electrical Engineering Study Program, Faculty of Engineering, Universitas PGRI Adi Buana Surabaya for the guidance, advice, and motivation given.

3. Mrs. Atmiasri, ST., M.T. as 2nd Examiner Lecturer and Lecturer, Electrical Engineering Study Program, Faculty of Engineering, Universitas PGRI Adi Buana Surabaya for the guidance, advice and motivation given.

4. Mr Drs. Widodo, S.T., M.Kom. as Supervisor and Lecturer, Electrical Engineering Study Program, Faculty of Engineering, Universitas PGRI Adi Buana Surabaya for the guidance, advice and motivation given.

5. All Lecturers of Electrical Engineering Study Program, Faculty of Engineering, Universitas PGRI Adi Buana Surabaya.

6. Mr. Muaji and Mrs. Sutami as my parents who always provide motivation to complete the Final Project.

7. Rossy Aprillia Agustiani, S.Ak, as my wife who always provides support to complete the Final Project.

8. The big family of Universitas PGRI Adi Buana Surabaya, especially the writers in the electrical laboratory, Electrical Engineering Study Program, Faculty of Engineering, for all their support, enthusiasm and cooperation.

\section{REFERENCE}

[1] Budiharto, Widodo, 2005. Panduan Lengkap Belajar Mikrokontroller Perancangan Sistem Dan Aplikasi Mikrokontroller.PT. Elex Media Komputido, Jakarta.

[2] Budiman, Frans. 2014. "Pemanggang Sate Otomatis Berbasis Arduino Uno". Universitas Gadjah Mada, Yogyakarta.

[3] Contaned Energy Indonesia PNPM.2013. Energy yang Terbarukan. Buku Panduan.
www.Containedenergy.com.24 November 2013

[4] Datasheet Atmel AT89s52, 2008. 8-bit Microcontroller With 8k Bytes In System Programmable Flash AT89s52

[5] Fadlisyah, Nurdin, Burhanuddin. 2014, Bahasa Assembly dalam Penerapnnya pada Microprocessor.Yogyakarta,Andi Offset

[6] Irawan, Asep. 2016.“ Rancang Bangun dan Uji Kinerja Tungku Panggangan”. Universitas Lampung, Bandar Lampung.

[7] Linda, 2019. "10 Jenis Ikan Yang Enak dibakar", Bacaterus.com.

[8] Setiawan, Afrie. 2011. 20 Aplikasi Mikrokontroler ATMega16 Menggunakan BASCOM - AVR. Yogyakarta: Penerbit ANDI.

[9] Rochman, Sagita, and Akbar Sujiwa. "Peningkatan Daya Output Generator Listrik Tipe Afpmg Pada Putaran Rendah Menggunakan 3 Rotor Dan 2 Stator."

[10] Sitinjak, Dallas. 2011.Alat Ukur Temperatur Berbasis Mikrokontroler ATMega8535 Dengan Tampilan LCD (Liquid Crystal Display). Skripsi Fisika Universitas Sumatra Utara. Tidak Diterbitkan.

[11] Sujiwa, Akbar, and Sagita Rochman. "Pengembangan Sistem Kontrol Serta Monitoring Suhu dan Volume Air Berbasis Web Pada Perangkat Desalinasi Air Laut." SNHRP (2019): 1-9.

[12] Wasito S, Pelajaran Elektronika, Gramedia Pustaka Utama, Jakarta. 